\title{
Consequences of 2003 Drought in Karnataka with Particular Reference to Livestock and Fodder
}

\author{
Nagaratna Biradar and K. Sridhar \\ Indian Grassland and Fodder Research Institute, Regional Research Station, \\ Dharwad 580 005, Karnataka, India
}

KEYWORDS Agriculture. Rainfall. Income During Drought. Fodder Value. Herd Size. Methods to Mitigate Drought

\begin{abstract}
Karnataka ranks second, next only to Rajstahan in India, in terms of total geographical area prone to drought. Among its 27 districts, 18 are drought prone. During the years, 2001-02, 2002-03 and 2003-04 it faced consecutive droughts. A study was conducted in 2004 to assess the consequences of 2002-03 drought in Karnataka with special emphasis on livestock and fodder components. Three districts of Karnataka (Chamrajnagar, Gadag and Gulbarga) each belonging to severely, moderately and less drought affected categories and representing three agro climatic regions were selected through multistage random sampling method. Data collected from 271 households was analysed. The annual income of the households reduced to half in drought year. The reduction was more in case of crops $(61.42 \%)$ followed by livestock $(30 \%)$ and labour $(20 \%)$. There was significant difference in the number of farmers purchasing fodder during normal $(50.92 \%)$ and drought years $(81.18 \%)$. Similarly significant difference was noticed for the average quantity of fodder purchased in normal (22.83q) and drought years (38.80q); per ton fodder value (Rs.2199 in normal and Rs.4166 in drought years); average distance traveled to purchase fodder $(4.25 \mathrm{~km}$ in normal and $44.07 \mathrm{~km}$ in drought years). In drought year, 17.34 percent households resorted to distress selling of livestock and the average herd size reduced from 4.15 ACU to 3.85 ACU. While majority (70.84\%) purchased fodder to mitigate drought effect, 32.10 percent of them fed less to the livestock than the usual quantity. The negative effects of drought on fodder and livestock would be reduced by enabling them to access fodder in a radius of $10 \mathrm{~km}$ of their habitation through fodder banks. This saves considerably their exorbitant expenditure towards transportation of fodder.
\end{abstract}

\section{INTRODUCTION}

Aberrant weather is a part of agriculture in India affecting its production. Only 20 per cent of cultivated land is irrigated. Drought and floods are the result of this aberrant weather making agriculture one of the weather sensitive industries. Floods, cyclones and storms have their adverse potential in a decreasing order of magnitude in view of limited area of occurrence. But, drought is extensive and prolonged when it occurs. As a result drought is considered as one of the biggest menace to agriculture among all weather related crisis. Rathore (2005) mentioned that the concept of drought varies from place to place depending upon normal climatic conditions, available water resources, agricultural practices and the various socio-economic activities of a region. The National Commission on Agriculture

Corresponding author address:

Dr. Nagaratna Biradar

Sr. Scientist and OIC, IGFRI-RRS

Dharwad 580 005, Karnataka, India

Telephone: 0836-2447150 (O); $2442880(\mathrm{R})$

Fax: 0836-2743459

E-mail:nagaratna123@rediffmail.com in India defines three types of droughts, namely meteorological, agricultural and hydrological droughts. Agriculture drought occurs when soil moisture and rainfall are inadequate during the growing season to support healthy crop growth to maturity and causes crop stress and wilting. Bandopadhyay (1988) argues that various forms of droughts get generate independently but inseparable and are linked to each other through the water cycle. Palmer (1964) reported that agricultural drought is probably the most important aspect of drought, but that problem is more specialized and complicated than some investigators seem to realize.

The agricultural drought, that is the non availability of water for normal crop growth is more acute in arid, semi-arid and dry sub humid regions. These regions constitute nearly 77 percent of the total land area in India and are consequently more prone to land degradation and frequent droughts. Past records indicate that in almost every year one part or other of the country has been subjected to drought, flood or cyclone. The drought prone tracts extend from Rajasthan to the peninsula including Karnataka. Two third of the geographical area of Karnataka state, which 
is confined roughly within 11.5 degree North and 18.5 degree North latitudes and 74 degree East and 78.5 degree East longitude is under arid and semi-arid conditions. Karnataka's total land accounts for 5.83 percent of the total area of the country (32.88 lakh sq.km) and ranks eighth among major states of the country in terms of size. Out of the total 27 districts, 18 are drought prone, with annual rainfall being less than $750 \mathrm{~mm}$. Therefore, in terms of the total geographical area which is drought prone, the state ranks $2^{\text {nd }}$, next only to Rajasthan and the probability of occurrence of drought in Karnataka is once in four years.

Drought leads to partial or complete crop failure. Due to recurring droughts for consecutive three years 2001-02, 2002-03 and 2003-04 the agriculture crops were adversely affected in almost all parts of Karnataka, the severity was more in the dry zones and where the soils are light and shallow. The livestock has a major role to play in subsistence rural agricultural economy. The livestock unfortunately, is dismally low in their productive capacities owing to several reasons. More than 70 percent of feed requirement of livestock is met by crop residues. Reduction in agricultural production during drought affects the livestock due to decreased availability of crop residues, in turn affecting the livelihood of farmers. A systematic and scientific study to assess the impact of drought of 2002-03 on fodder resources and farm income of the family was undertaken using primary data collected through personal interview technique in 2004 in Karnataka to aid livestock related responses in drought. The results of this study are presented and discussed in this paper. Some studies have dealt with the impact of drought on agriculture, livestock and livelihood in home and abroad (Bidinger et al. 1991; Scoones 1992; Falchamps et al. 1998; Sweet 1998; Rathore 2004; Rathore 2005; Pandey and Bhandari 2006; Glordano and Villholth 2007; Herani et al. 2008). However many of the studies are based on analysis of data from secondary sources and very few studies (Rathore 2004) made use of primary data for drawing conclusions.

\section{Objectives}

The objectives of the present study are

- Study the changes in purchase of fodder during normal and drought years

- Assess the annual income of farmers from different sources during normal and drought years

- Study the alternative methods used by the farmers to mitigate fodder shortage in drought

\section{SAMPLING METHODOLOGY}

Karnataka faced consecutive droughts since 2001. The drought of 2003 was considered of severe nature and the study emphasized to analyse effect of 2003 drought on livestock and fodder situation in the state. Secondary data on average rainfall of each district during the year 2002-03 was collected from the Drought Monitoring Cell, Government of Karnataka. Percent rainfall deficiency for each district was calculated. Three districts (Chamrajnagar, Gadag and Gulbraga) each belonging to severely affected (rainfall deficiency of more than $50 \%$ Long Period Average), moderately affected (between 35-50 \% LPA) and less affected (less than $35 \%$ LPA) categories were selected using multistage random sampling based on the percent rainfall deficiency These three districts represent three agro climatic regions of the state. Also they were so chosen as they are located geographically each in northern, southern and central part of Karnataka, in order to gather data from representative sample of the whole state. Secondary data on area under different crops in the state as well as in each of the selected study districts were collected. This was felt essential as more than two third of the livestock diet constitutes crop residues. Primary data was collected using pre-tested standardised interview schedule comprising 21 parameters. Interview schedule was structured in such a way that the questions to obtain data from normal year as well as drought year were incorporated for relevant parameters. This enabled the researcher not only to compare but also to know the extent of difference between these years. Normal year refers to the year of which normal rainfall received. Drought year refers to the deficiency of precipitation over an extended period of time, resulting in a water shortage for some activity, group, or environmental sector. Standardised interview schedule was used to collect the data from 100 farmers in each selected district, together 300 farmers, belonging to different socio economic groups. Of the 300 interview schedule 29 were rejected as the information gathered was neither complete nor erroneous. The data of 271 respondents was hence utilized for final tabulation and statistical 
analysis. The data was collected between October-November 2004 and was analysed using appropriate statistical tools.

\section{RESULTS AND DISCUSSIONS}

\section{Annual Rainfall in 2003}

The state received annual rainfall of $876 \mathrm{~mm}$ in 2003 as against the normal value of $1139 \mathrm{~mm}$. So $23 \%$ less rainfall was received and the state thus was in deficit category. In 2002 the percent deficiency of rainfall was slightly higher and was $24 \%$ less than the normal. The actual total rainfall was $867 \mathrm{~mm}$. Perusal of figure 1 indicates that the percentage departure of annual rainfall during 2003 was the third highest for the period from 1970 to 2003. The figure 1 also depicts a deficit rainfall since 2001 .

\section{Agriculture Situation of Karnataka in 2003-04 drought}

During 2003, a total of 94.12 lakh ha. was sown as against the normal of 168.89 lakh ha. During 2003, the area under total cereals was 48.54 lakh ha that mounts to $76 \%$ of the normal. The area was covered mainly by jowar, maize, rice, ragi, bajra, wheat and minor millets. In case of pulses, the area sown was 12.97 lakh ha. In case of oilseeds, the area sown was 22.2 lakh ha (58\% of the normal). The area covered was highest in case of sunflower followed by groundnut, sesamum and other oilseeds. In case of cashcrops, the coverage was very less and it was $34 \%$ of the normal. The area covered as percentage of normal under cashcrops was: tobacco - 43\%; sugarcane - 54\% and cotton - 19\%.During 2003, total coverage by all crops for the state as a whole was $56 \%$ of the normal. The coverage in general was not satisfactory for cereals, pulses and oilseeds. The coverage was very less i.e., $34 \%$ of the normal in case of cash crops. Figure 2 provides a diagrammatic representation of the coverage by various crop groups.

\section{Agriculture Situation in the Study Districts in 2003-04}

Perusal of Table 1, reveals that in Chamarajnagar, the severely drought affected district, the area under total cereals was $65 \%$, pulses was $109 \%$, oilseeds $77 \%$ and cash crops was $18 \%$ of the normal. In moderately drought affected Gadag district, the area under total cereals was 54\%, pulses was $39 \%$, oilseeds was $68 \%$ and cash crops was $21 \%$. In the Gulbarga district which was less drought affected, the area under total cereals was $67 \%$, pulses was 39\%, oilseeds was $78 \%$ and cash crops was $40 \%$. All the three districts

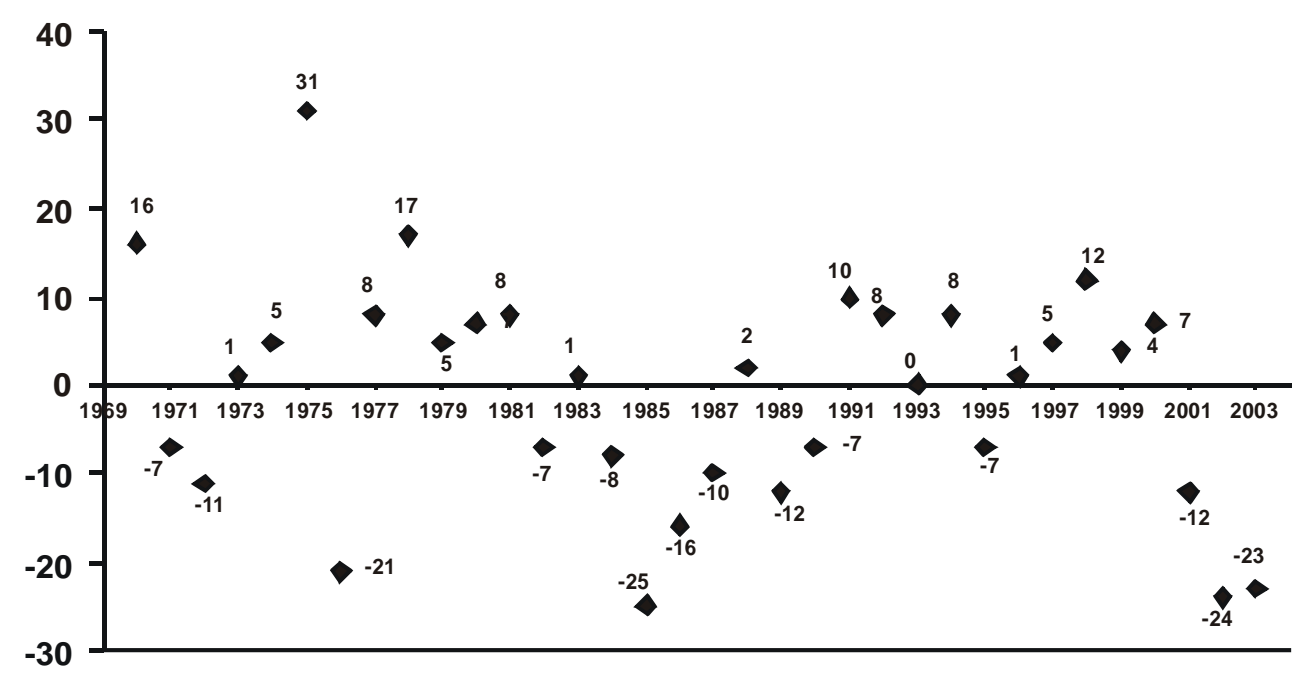

Fig. 1. Percentage departure of annual rainfall from normal for Karnataka Comparison on $2001,2002 \& 2003$ with last 34 years 
Table 1: Area under different crops in study districts (area in thousand ha)

\begin{tabular}{|c|c|c|c|c|c|c|}
\hline \multirow[t]{2}{*}{ Crops } & \multicolumn{2}{|c|}{ Chamrajnagar } & \multicolumn{2}{|c|}{ Gadag } & \multicolumn{2}{|c|}{ Gulbarga } \\
\hline & Actual & 2003 & Actual & 2003 & Actual & 2003 \\
\hline Cereals & 110.232 & 71.82 & 246.38 & 133.91 & 615.9 & 411.37 \\
\hline Pulses & 44.081 & 48.121 & 178.974 & 69.69 & 1555.8 & 607.46 \\
\hline Oilseeds & 31.375 & 24.227 & 186.89 & 126.22 & 334.88 & 260.99 \\
\hline Cash crop & 86.785 & 15.217 & 188.9 & 39.32 & 69.66 & 27.94 \\
\hline
\end{tabular}

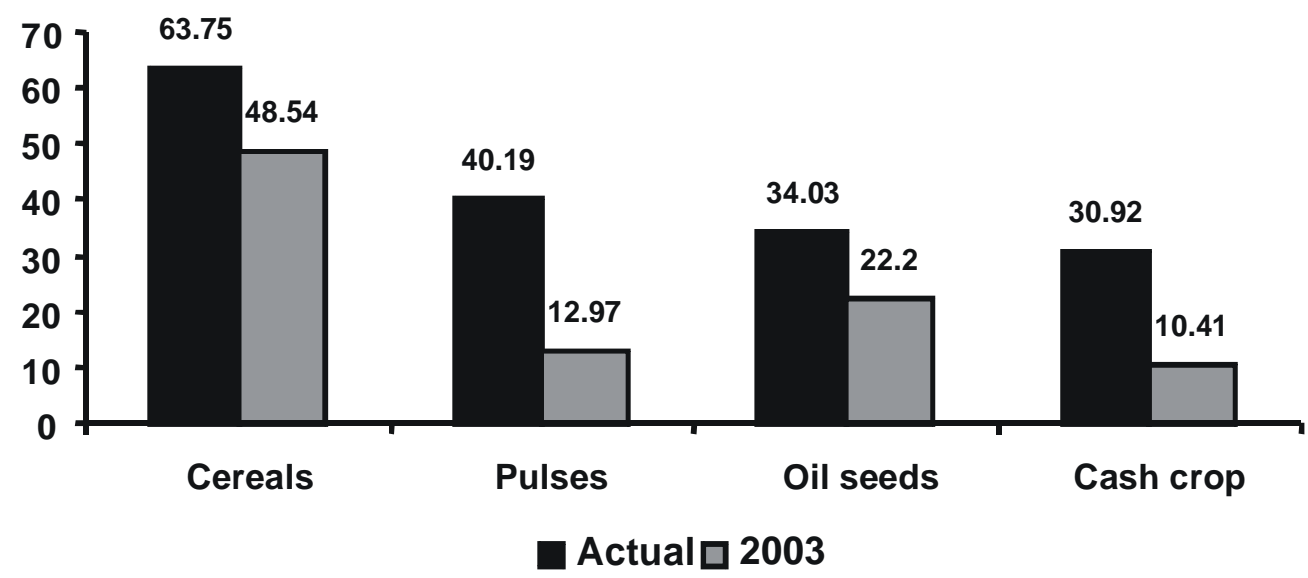

Fig. 2. Area under different crops in Karnataka during normal rainfall year and in 2003 (area in lakh ha)

experienced meteorological, hydrological and agricultural drought during all the seasons of 2003. Agricultural drought is characterised by deficiency in water availability including soil moisture for specific agricultural operations.

\section{Socio Economic Profile of the Households}

Nearly half $(47.97 \%)$ of the respondents belonged to forward castes. Among the remaining almost equal percent of the respon-dents belonged to other backward castes $(22.87 \%)$ and schedule castes (20.29\%). Only 8.85 per cent of the respondents belonged to schedule tribes. Majority of the respondents $(42.80 \%)$ belonged to middle age group and almost equal percent of them belonged to young (less than 35 years, $27.30 \%$ ) and old age (more than 50 years, $29.88 \%$ ) groups (Table 2). The average age of the respondents was 45 years. The average education of the respondents was 4 years of formal schooling i.e. $4^{\text {th }}$ standard. However almost half of the respondents (46.49\%) were illiterates followed by primary educated (29.15\%), high school educated $(13.65 \%)$ and college and above $(10.70 \%)$. Each half of the respondents belonged to nuclear $(49.45 \%)$ and joint $(50.55 \%)$ family systems. The

Table 2: Socio-economic profile of the respondents

\begin{tabular}{lrr}
\hline Particulars & Number & $\%$ \\
\hline Age & & \\
$<35$ & 74 & 27.30 \\
$35-50$ & 116 & 42.80 \\
$>50$ & 81 & 29.88 \\
Average & 45.59 & \\
Education & 126 & 46.49 \\
$\quad$ Illiterate & 79 & 29.15 \\
$\quad$ Primary educated & 37 & 13.65 \\
Highschool & 29 & 10.70 \\
College and above & 4.06 & \\
Average & & \\
Family Size & 138 & 50.92 \\
Small (<5) & 133 & 49.08 \\
Big (>5) & 6.33 & \\
Average & & \\
Family Type & 134 & 49.45 \\
$\quad$ Nuclear & 137 & 50.55 \\
Joint & & \\
Land Holding & 17 & 6.27 \\
Landless & 159 & 58.67 \\
Small (2 ha) & 46 & 16.97 \\
Medium (2-4ha) & 49 & 18.08 \\
Big (> 4 ha) & 2.77 & \\
Average &
\end{tabular}


landless respondents constituted only 6.27 percent, where as more than half $(58.67 \%)$ of them owned small land holdings of 1-2 ha. Almost equal percent of the respondents owned medium size (2-4ha, 16.97\%) and big size (>4ha, 18.08\%) land holdings. The average land holding size of the respondents was 2.77 ha.

\section{Change in Annual Income of the Respondents in Drought Year}

As presented in Table 3, about three fourth (75.64\%) of the respondents earned annually more than Rs.11500, the average being Rs.30957 during the normal rainfall years. In the drought period, this percent reduced to 31.36 and majority $(68.63 \%)$ earned less than Rs.11500 and the average annual income during drought was Rs.15178.33, half of the income of normal rainfall year. Sweet (1998) reported that income of the communal area households in Namibia reduced to a quarter of average monthly income during 1992 due to crop losses, livestock mortality and reduced employment opportunities. Glordand and Villholth (2007) reported that there was an overall drop in income to $33 \%$ of its previous levels by the end of the 4 year drought. Similarly in the present study, the consequences of drought were rather sever given the size of shortfall in income suffered by many households during the drought year. Rathore (2004) reports change in occupation and migration due to drought. Drought in 200203 had a significant impact on the occupations of people as $80 \%$ of farmers were forced to join the labour force, both at relief sites and outside villages.

Table 3: Annual income of the respondents in normal and drought year

\begin{tabular}{|c|c|c|}
\hline & Number & $\%$ \\
\hline \multicolumn{3}{|c|}{ Annual Income-Normal year } \\
\hline$<11500$ & 66 & 24.35 \\
\hline$>11500$ & 205 & 75.64 \\
\hline Average & 30957.09 & \\
\hline \multicolumn{3}{|c|}{ Annual Income-Drought year } \\
\hline$<11500$ & 186 & 68.63 \\
\hline$>11500$ & 85 & 31.36 \\
\hline Average & 15178.33 & \\
\hline
\end{tabular}

\section{Change in herd size of the respondents in drought year}

Herani et al. (2008) reported in their study conducted at Tharparkar Province of Pakistan that the important component of agricultural sector is livestock and is an insurance against harvest failures and a source of easily cashable investment capital. Ninety two percent of families have opined that livestock is the only first level sustainable source of livelihood. Owing to its importance the present study analysed the change in herd size in drought year. Perusal of Table 4 reveals that in the normal rainfall year the average livestock holding was 4.15 Adult Cattle Units. Forty-one percent of the respondents owned 2 ACUs, $30.25 \%$ respondents owned 4 ACUs, 15.13 $\%$ owned 5-6ACUs and the remaining owned $(12.91 \%) 7 \&$ above ACU. The drastic reduction in livestock holding was not observed during drought year, but the average size reduced to 3.85 ACUs. Bidinger et al. (1991) reported that in 1986 drought in Mahaboobnagar district of Andhra Pradesh, only 2 farmers from the study sample reported to livestock sales. Herd size was not noticeably affected in the present study due to drought. Herani et al. (2008) analyzed effect of 2000 drought and observed that livestock losses in terms of mortality and forced culling were observed in the order of $10 \%$ for cattle, $30 \%$ for sheep and $20 \%$ for goats in the worst affected district of Sindh. Sweet (1998) found that as many as $80 \%$ of communal area livestock owners suffered losses. Drought mortality reduced the median flock size of goats from 30 to 17 and of sheep from 26 to 18 , leaving most flocks well below the considered minimum viability level of 30-35 head. Cattle losses averaged to $22 \%$ in communal areas. Rathore (2005) reported that in Rajasthan livestock in large numbers perished, due to 2003 drought ranging between 10 to $32 \%$ of the

Table 4: Herd size of the respondents in normal and drought year

\begin{tabular}{|c|c|c|}
\hline & Number & Per centage \\
\hline \multicolumn{3}{|c|}{ Livestock Owned (ACU)-Normal year } \\
\hline 2 & 112 & 41.33 \\
\hline 4 & 82 & 30.25 \\
\hline 6 & 41 & 15.13 \\
\hline 8 & 16 & 5.90 \\
\hline 10 & 19 & 7.01 \\
\hline Average & 4.15 & \\
\hline \multicolumn{3}{|c|}{ Livestock Owned (ACU)-Drought year } \\
\hline 2 & 118 & 43.54 \\
\hline 4 & 81 & 29.88 \\
\hline 6 & 38 & 14.02 \\
\hline 8 & 14 & 5.16 \\
\hline 10 & 19 & 7.01 \\
\hline Average & 3.85 & \\
\hline
\end{tabular}

ACU: Adult Cattle Units 
population. Further he reported that losses of cows were much higher (25 to 50) as most of them were either abandoned due to starvation or put in charity centers, because of acute shortage of fodder and finances.

\section{Purchase Details of Fodder During Normal and Drought Year}

Perusal of Table 5 reveals that in normal year $50.92 \%$ of farmers of Karnataka purchased fodder and feeds. This was increased to $81.18 \%$ during drought year. The t-test calculated thus showed significant difference in the number of farmers purchasing fodder during normal and drought years. While majority of the farmers purchased concentrate feeds in normal year, during drought farmers purchased crop residues also. In normal year, none purchased sorghum stover, but in drought year nearly half $(43.24 \%)$ of the respondents purchased it. As per DARE report 2003, drought year 2002-03 saw Karnataka face serious problems on the side of cattle fodder. Further it reported that the shortage of fodder quite an extent was caused by outflow of rabi Jowar stocks from Karnataka to neighboring Maharashtra and Tamil Nadu.

Purchase of paddy straw by the number of farmers was more than doubled in drought year $(37.71 \%)$ when compared to normal year $(16.97 \%)$. On the contrary, number of farmers purchasing concentrate feed reduced to half in drought $(23.61 \%)$ from $46.49 \%$ in normal year. Similar trend was observed for the purchase of rice bran as number of farmers purchasing it reduced from $28.78 \%$ in normal year to $17.71 \%$ in drought. None purchased hay of legume crops and other crop residue in normal year. But in drought, 8.85 per cent of them purchased the former and $9.22 \%$ the latter. This indicates that maintenance feed of the livestock was though addressed by the farmers but with an extra cost. In a drought situation, with the non-availability of adequate and quality fodder, providing cattle feed to cover a part of the daily requirement of animals is essential. The increase in the cost of feed almost by 30 percent, especially by Karnataka Milk Federation (DARE. 2003) due to hike in the price of raw materials aggravated the situation further affecting livestock health and productivity.

The average quantity of fodder and feeds purchased by the farmers during normal year was $22.83 \mathrm{q}$ and increased to $38.80 \mathrm{q}$ in drought year, up by $69.95 \%$, in spite of increase in the cost of fodder and feeds. Significant difference was hence found in the quantity of fodder and feeds purchased during the years under comparison.

The value of fodder per ton including cost towards labour and transport worked out was Rs.2199 in normal year that was almost doubled (Rs.4166) during drought years. According to DARE report, the fodder prices in Karnataka went up to 75 per cent higher than the normal during November 2002, February 2003 and peaked again in May-June 2003. In many cases the cost of transportation exceeded the actual cost of fodder. For instance in Chamarajnagar district, they purchased paddy straw from the Kabini command

Table 5: Purchase details of fodder during normal and drought year

\begin{tabular}{|c|c|c|c|c|c|}
\hline S. No. & Particulars & Normal year & Drought & Difference (\%) & $t$-value \\
\hline \multirow[t]{3}{*}{ I } & Purchasing of fodder & & & & \\
\hline & Purchased & $138(50.92)$ & $220(81.18)$ & +30.26 & $9.84 * *$ \\
\hline & Not purchased & $133(49.08)$ & $51(18.81)$ & & \\
\hline \multirow[t]{7}{*}{ II } & Types purchased & & & & \\
\hline & Sorghum stover & & $117(43.24)$ & +43.24 & \\
\hline & Paddy straw & $46(16.97)$ & $102(37.71)$ & +20.74 & \\
\hline & Concentrated feeds & $126(46.49 \%)$ & $64(23.61)$ & -22.88 & \\
\hline & Bran (Rice/wheat) & $78(28.78 \%)$ & $48(17.71)$ & -11.07 & \\
\hline & Hay of legume crops & & $24(8.85)$ & +8.85 & \\
\hline & others & & $25(9.22)$ & +9.22 & \\
\hline \multirow[t]{4}{*}{ III } & Purchase details & & & & \\
\hline & Av. Quantity purchased/farmer (q) & $22.83 \mathrm{q}$ & $38.80 \mathrm{q}$ & +15.97 & $2.07 * *$ \\
\hline & Value/t (Rs.) & 2199 & 4166 & +1967 & $11.52 * *$ \\
\hline & Av. Distance traveled to buy & $4.25 \mathrm{~km}$ & $44.07 \mathrm{~km}$ & +39.82 & $4.82 * *$ \\
\hline \multirow[t]{3}{*}{ IV } & Selling of livestock & & & & \\
\hline & $\begin{array}{l}\text { Farmers resorted to distress selling } \\
\text { of livestock in drought years }\end{array}$ & & $47(17.34)$ & & \\
\hline & Av.no.of ACU sold & & 2.55 & & \\
\hline
\end{tabular}

Figures in parenthesis indicate percentages: ** Significant at 1 per cent level of probability 
area, situated next to the district, where it was available plenty at cheaper rate. But increased expenditure on transportation of fodder increased its overall cost.

The farmers traveled average of $4.25 \mathrm{~km}$ radius to purchase the fodder in normal year. This distance traveled in drought years increased 10 times as they had to travel an average distance of $44.07 \mathrm{~km}$.

The encouraging result was that the distress selling of livestock due to lack of fodder was resorted to by only 17.34 per cent of the farmers. Among those who resorted to selling of livestock, an average of $2.55 \mathrm{ACU}$ were sold to the middlemen of slaughter houses at throw away price. Similar finding was also reported by DARE attributing the reason to considerable emphasis placed in fodder management and establishment of cattle camps by the state government. However majority of the farmers resorted to distress selling were marginal and small farmers. Livestock for these farmers acts as an important livelihood source and devoid of fodder in common property resources, on which they heavily depend, affected them.

\section{Annual Income from Different Sources During Normal and Drought Year}

Results of the average annual income, defined as net returns to family owned resources which include family labour and livestock, capital and land, of farmers during normal and drought years are presented in Figure 3. Overall reduction of annual income was by fifty per cent in drought year. Percent reduction was more in case of income from crops $(61.42 \%)$, followed by livestock $(30 \%)$ and least by others-labour (20\%). Bidinger et al. (1991) reported similar findings that due to drought there was sharp fall in the share of crop income. Sources of crop revenues literally dried up as the share of crop income fell from $58 \%$ of net household income before the drought to $7 \%$ in the second drought year. However the effect of income reduction due to livestock, as observed during field work, was more pronounced for small and marginal farmers. While annual income of $75.64 \%$ farmers in normal year was more than Rs. 11500 (ceiling fixed by Department of revenue, GoK for families below poverty line), in drought years only $31.36 \%$ of farmers reported that their annual income crossed above Rs. 11500.

Pandey and Bhandari (2006) reported that in Chhattisgarh, Jharkhand, and Orissa, almost 13 million people who sit perilously just above the poverty line fall back below it due to droughtinduced income loss. The total farm household income can drop by 40 to 80 percent in drought years relative to normal years.

\section{Methods Used By the Farmers to Mitigate Fodder Shortage}

Many programmes were implemented by GoI

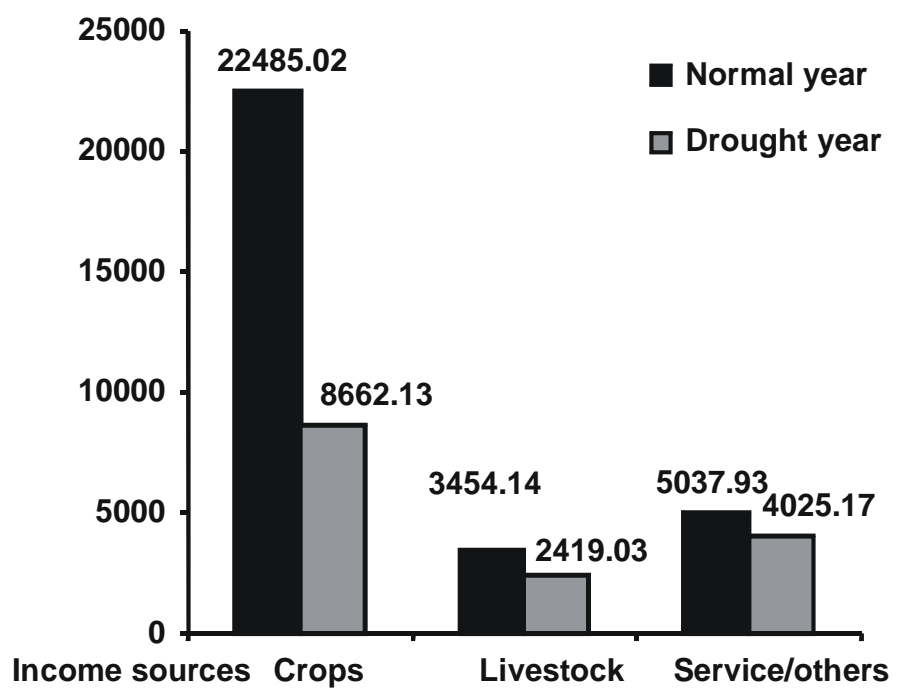

Fig. 3. Annual income of farmers in rupees during normal and drought years 
to combat drought. Of these, Drought Prone Area Programme was the earliest area development programme launched by the Central Government in 1973-74 to tackle the special problems faced by those fragile areas, which are constantly affected by severe drought conditions. Since then many programs were implemented including food for work programme. However what methods farmers resort to combat drought effect is not studied much. Farmers in the study area used their own methods to mitigate fodder shortage and the findings pertaining to this aspect are presented in Table 6. While majority $(70.84 \%)$ purchased fodder, $32.10 \%$ of them fed less to the livestock than the usual quantity. Other two methods followed were to sell livestock (17\%) and grow sorghum or maize exclusively for fodder purpose (13.28\%).

Table 6: Methods used by farmers to mitigate fodder shortage in drought

\begin{tabular}{llrr}
\hline S. No. & Methods & Number & $\%$ \\
\hline 1 & Purchase of fodder & 220 & 81.18 \\
2 & Feed less than usual & 87 & 32.10 \\
& quantity to livestock & & \\
3 & Grow sorghum/maize & 36 & 13.28 \\
4 & Sell livestock & 47 & 17.34 \\
5 & Release livestock & 2 & 0.74 \\
\hline
\end{tabular}

\section{CONCLUSIONS}

Study has clearly brought out that there was sever reduction in the annual income of the respondents during drought year. However, reduction in income from livestock was less pronounced as compared to crops. Livestock component thus gave more stability to the income of the farmers. Given this fact, farmers resorted to only sustenance feeding of livestock affecting its productivity, owing to the huge cost involved in fodder transportation. Even one third of the farmers though not opted for distress selling, but fed less to the livestock. Livestock as is less prone to variation in rainfall and other climatic factors, the study recommends that in such conditions livestock component should be given special emphasis. This could be achieved by providing farmers better access to fodder. Establishing fodder banks in the near vicinity of villages, might be in the radius of $10 \mathrm{~km}$, improves the livestock health coupled with reducing the drought effect on income of the farmers. This would surely decrease the negative impact of drought on the livelihood of farming community.

\section{REFERENCES}

Bandopadhya J 1988. Water scarcity: By choice. Seminar, 346: 24-27.

Bidinger PD, Walker TS, Sarkar B, Ram Murthy, Babu P 1991. Consequences of mid drought: longitudinal evidence from Mahboobnagar. Economic and Political Weekly, 26: A105-A114.

DARE 2003. Drought 2002 States Report-AP, Karnataka and Tamil Nadu. New Delhi: Department of Agriculture Research and Education, Ministry of Agriculture, Government of India.

Falchamps M, Christopher U, Czukas K 1998. Drought and saving in West Africa: Are livestock a buffer stock? Journal of Development Economics, 55(2): 273-305.

Glordano M, Villholth KG 2007. The agricultural groundwater revolution: opportunities and threats to development. Comprehensive Assessment of Water Management in Agriculture Series. Srilanka: International Water Management Institute

Herani GM., Wasim P, Rajar AW and Shaikh RA 2008. Livestock: A reliable source of income generation and rehabilitation of environment at Tharparkar. Paper No.8700 Munich Personal RePEc Archive, Biztek: Indus Institute of Higher Education, Karachi University, Sindh University.

Sweet J, 2004. Livestock-coping with drought: NamibiaA case study, Northern region development project, Tsumeb, Namibia (1998) From the official home page of Overseas Development Institute www.odi. org.uk/pdn/drought/sweet.pdf (Retrieved October 9, 2004)

Palmer WC 1965. Meteorological drought. Research paper no.45, Washington D.C.: Office of climatology, U.S.Weather Bureau.

Pandey S, Bhandari H 2006. Drought perpetuates poverty. Rice Today, April-June: 37.

Rathore MS 2004. Adaptive Strategies to droughts in Rajasthan. Jaipur: Institute of Development Studies.

Rathore MS 2005. State level analysis of drought policies and impacts in Rajasthan, India; Colombo, Srilanka. Working paper 93, Srilanka: International Water Management Institute

Scoones I 1992. Coping with drought: Responses of herders and livestock in contrasting savanna environments in southern Zimbabwe. Human Ecology, 20(3): 293-314. 